
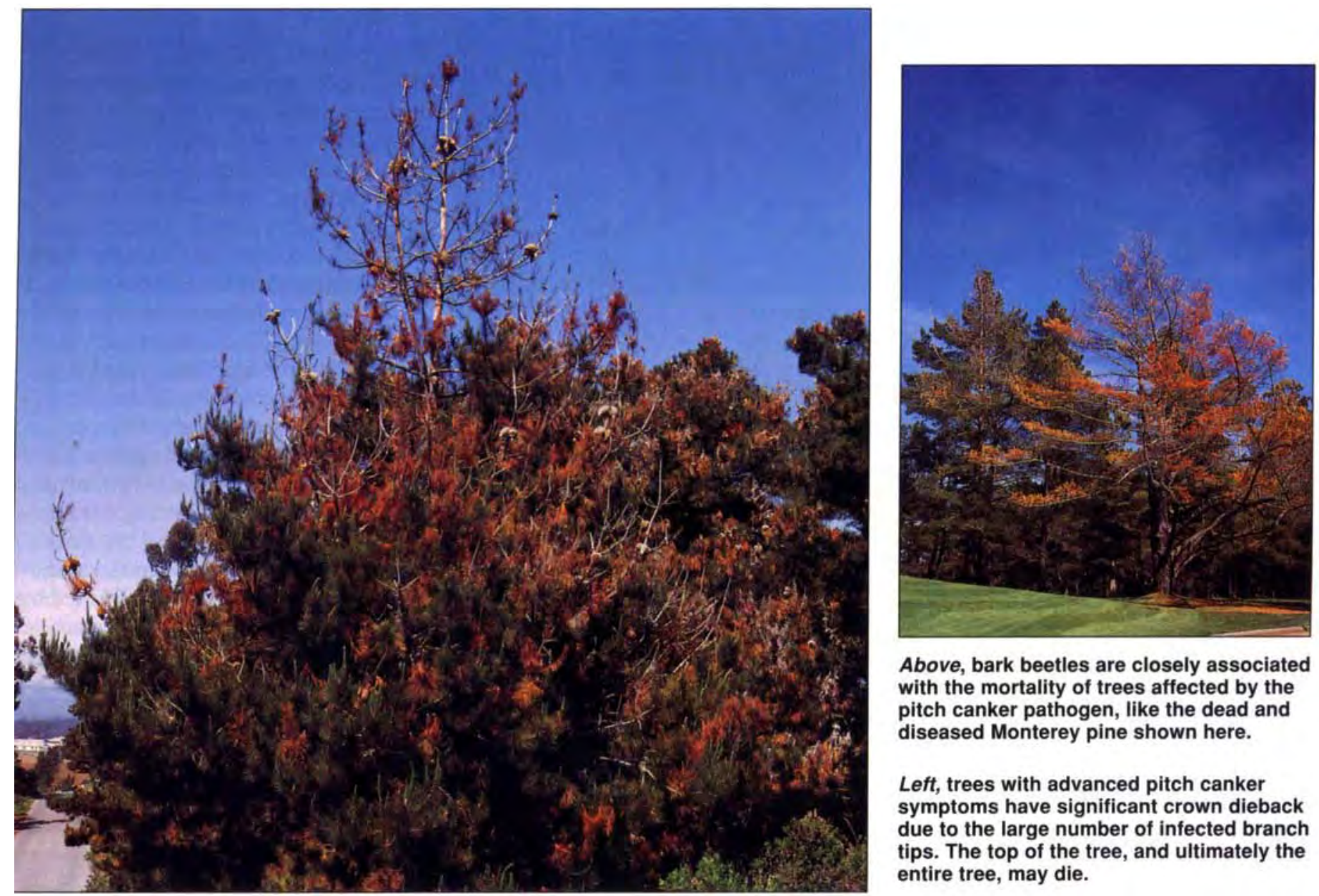

Above, bark beetles are closely associated with the mortality of trees affected by the pitch canker pathogen, like the dead and diseased Monterey pine shown here.

Left, trees with advanced pitch canker symptoms have significant crown dieback due to the large number of infected branch tips. The top of the tree, and ultimately the entire tree, may die.

\title{
Pitch canker kills pines, spreads to new species and regions
}

\author{
Andrew J. Storer \ Thomas R. Gordon $\square$ Paul L. Dallara $\square$ David L. Wood
}

The host and geographic range of the pitch canker pathogen has greatly increased since it was first discovered in California in 1986. Most significantly, it now affects many pine species, inc/uding native stands of Monterey pine, and has made a transgeneric jump to Douglas fir. Isolated occurrences of the disease have been found as far north as Mendocino County. Insects are strongly implicated as vectors of the pathogen, and longterm management appears to be dependent on the development of resistant tree varieties. In infested regions, the planting of Monterey pine and other pine tree species should be undertaken with caution.
Pitch canker disease was first identified in California at New Brighton State Beach, Santa Cruz County, in 1986. By the beginning of 1992, it was recorded as far north as San Francisco and as far south as San Diego County. Most records were from Monterey pine, but occasional infections of bishop, Coulter, Italian stone, Aleppo, ponderosa and Canary Island pine were reported. The most extensive infestations were in Santa Cruz and southern Alameda counties. In Southern California, with the exception of an isolated infestation in Santa Barbara County, only Monterey pine Christmas tree plantations were affected.

Pitch canker disease, caused by the fungus Fusarium subglutinans f. sp. pini, is characterized by a resinous exudation on the surface of shoots, branches, exposed roots and boles of infested trees. Removal of bark from an infected area reveals slightly sunken, honey-colored wood that is soaked with resin. Needles on the tips of infected branches fade from yellow to red and fall from the tree. Previously vigorous, unshaded branches often lose all needles beyond the most recent cone whorls, producing a noticeable dieback in the tree crown. Female cones abort before or after reaching full size, and remain closed on infected whorls. Cankers on the tree bole produce large amounts of resin that often coat the bark several feet below the infection site; lower limbs and understory vegetation are also sometimes covered in fallen pitch. Bole 
cankers are flat or slightly sunken, up to about $30 \mathrm{~cm}$ in diameter, and usually appear after branch dieback has occurred. Trees with advanced symptoms of the disease have significant crown dieback due to the large number of infected branch tips. The top of the tree, and ultimately the entire tree, may be killed.

The pitch canker fungus has been isolated from a number of beetle species that are commonly associated with Monterey pine and several other hosts. These are implicated as vectors of the pathogen (table 1). The pathogen has also been isolated from several predators and parasites of these insects.

The larvae of these beetles are whitish in color and grublike in appearance, and feed in the phloem or woody tissues of trees. With the exception of the dry twig and cone beetle, the larvae are legless, and the adult beetles are cylindrical with small clubbed antennae. Adult cone beetles are 3 to $5 \mathrm{~mm}$ long, and often produce a small pitch tube where they mine into a cone. The twig beetles are 2 to 3 $\mathrm{mm}$ in length, and their presence is indicated by holes $1 \mathrm{~mm}$ in diameter in twigs, cones and cone stalks. Removal of the bark reveals irregular radiating galleries lightly engraving the woody tissue. Upon dissection, the galleries of the twig beetles can be found inside the twig, often traveling to the pith. The dry twig and cone beetle is elongate, about 4 to $5 \mathrm{~mm}$, with threadlike antennae, with the last three segments enlarged. They enter cones through entrance tunnels excavated by scolytid beetles. Cones infested with any of these species are usually aborted by the tree.

The engraver beetles are 4 to $7 \mathrm{~mm}$ in length, and their presence is indicated by holes $2 \mathrm{~mm}$ in diameter in the bark of the bole and larger branches. Their tunneling activity produces a reddish-brown boring dust. Removal of the bark reveals a gallery system consisting of long female-excavated galleries of uniform diameter with smaller larval galleries radiating from them. The larval galleries increase in size along their length. Staining of the wood by naturally associated fungi is usually present.
Available evidence indicates that the twig beetles and the cone beetle carry the pathogen to branch tips and cone whorls, and individual trees usually have multiple infections. Engraver beetles have been shown to transmit the fungus to the bole of the tree.

Some of these insects have wide host ranges, and therefore may be capable of vectoring the pathogen to more than one tree species.

Symptoms of pitch canker may appear at any time of year, but most new symptoms have been observed in spring and early fall, possibly due to increased twig and cone beetle activity at these times. Symptoms are often accompanied by death of twigs, limbs, tree tops and entire trees due to the pathogen and/or bark beetle attack. Positive identification of the pathogen requires laboratory isolation and culture of the fungus from symptomatic tissue.

\section{Isolation of the fungus}

Trees with symptoms of pitch canker were sampled by collecting symp- tomatic branch tips from the canopy using pole pruners. Isolations of infected tissue were made in the field and/or in the laboratory. Samples of resin-soaked phloem and xylem tissue were removed, surface sterilized by immersing in $1 \%$ hypochlorite solution for 30 seconds, and placed on an agar medium selective for Fusarium spp. Plates of this medium were incubated at room temperature under a 12:12 lighting regime for 5 days. Fungal colonies were observed under a dissecting microscope. Colonies suspected of being the pitch canker pathogen were reisolated onto carnation leaf agar. Identification of the fungus as F. subglutinans was then possible. Insects collected from the plant material were also identified, killed by freezing, and plated onto the selective agar medium. Pathogenicity of isolates recovered from insects or plant material was confirmed by inoculating Monterey pines in the greenhouse and noting the development of resinsoaked lesions 3 to 4 weeks after inoculation.

\begin{tabular}{|c|c|c|}
\hline \multicolumn{3}{|c|}{$\begin{array}{l}\text { TABLE 1. Insects from which the pitch canker fungus has been isolated, } \\
\text { and which are possible vectors of the pathogen }\end{array}$} \\
\hline Common name & Latin name & Family \\
\hline \multirow[t]{4}{*}{ Twig beetles } & Pityophthorus nitidulus & Scolytidae \\
\hline & P. pulchellus tuberculatus & Scolytidae \\
\hline & P. carmeli & Scolytidae \\
\hline & P. setosus & Scolytidae \\
\hline Cone beetie & Conopthorus radiatae & Scolytidae \\
\hline Dry twig and cone beetle & Ernobius punctulatus & Anobiidae \\
\hline \multicolumn{3}{|l|}{ Engraver beetles } \\
\hline California five-spined ips & Ips paraconfusus & Scolytidae \\
\hline Monterey pine ips & 1. mexicanus & Scolytidae \\
\hline California four-spined ips & 1. plastographus & Scolytidae \\
\hline \multicolumn{3}{|c|}{$\begin{array}{l}\text { TABLE 2. Tree species found infected with the pitch canker fungus in the field, } \\
\text { and species susceptible to the disease in laboratory tests }\end{array}$} \\
\hline \multirow{2}{*}{\multicolumn{2}{|c|}{$\begin{array}{l}\text { Tree species } \\
\text { Common name }\end{array}$}} & Native to \\
\hline & & California \\
\hline \multicolumn{2}{|l|}{ Naturally infected species } & 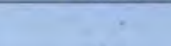 \\
\hline Aleppo pine & Pinus halepensis & No \\
\hline Bishop pine & Pinus muricata & Yes \\
\hline Canary Island pine & Pinus canariensis & No \\
\hline Coulter pine & Pinus coulteri & Yes \\
\hline Digger pine & Pinus sabiniana & Yes \\
\hline Italian stone pine & Pinus pinea & No \\
\hline Knobcone pine & Pinus attenuata & Yes \\
\hline Monterey pine & Pinus radiata & Yes \\
\hline Monterey $\mathrm{x}$ knobcone pine & Pinus radiata $x$ attenuata & Yes \\
\hline Ponderosa pine & Pinus ponderosa & Yes \\
\hline Shore pine & Pinus contorta contorta & Yes \\
\hline Torrey pine & Pinus torreyana & Yes \\
\hline Douglas fir & Pseudotsuga menziesii & Yes \\
\hline \multicolumn{3}{|c|}{ Other species susceptible in laboratory tests } \\
\hline Eldarica pine & Pinus eldarica & No \\
\hline Jeffrey pine & Pinus jeffreyi & Yes \\
\hline Sugar pine & Pinus lambertiana & Yes \\
\hline Scotch pine & Pinus sylvestris & No \\
\hline
\end{tabular}




\section{Pitch canker spreads}

New host species. The pitch canker fungus was isolated from shore pine from the south campground at Sunset State Beach, Santa Cruz County, in February 1992. Other shore pines with symptoms of pitch canker in the area have been observed since that time. In April 1992 a single Torrey pine at Seacliff State Beach, Santa Cruz County, was confirmed to be infected with the pathogen. In May 1993 the pathogen was isolated from symptomatic gray (= Digger) pines near Soquel Avenue in Santa Cruz County and from knobcone pine and Douglas fir at Monterey Bay Academy, Santa Cruz County. All of these records represent tree species not previously observed to have pitch canker as a result of naturally occurring infections. In November 1992 an Aleppo pine in a Christmas tree plantation in San Diego county was found to be infected with the pathogen. This is the first record of pitch canker in Southern California on a tree species other than Monterey pine. A summary of tree species known to be naturally infected with the pitch canker fungus, and other tree species shown to be susceptible in greenhouse tests, is given in table 2.

New geographic areas. Pitch canker has been observed in two of the three mainland native Monterey pine stands. On the Monterey Peninsula, pitch canker was confirmed on two trees at the Pebble Beach firehouse in April 1992. By December 1992, over 20 trees in the immediate area showed symptoms of the disease. Three other infested areas have been found on the Monterey Peninsula. In March 1993 pitch canker infections were confirmed on a number of trees at Asilomar State Park, and in June 1993 symptomatic trees were observed at Spanish Bay. In June 1992 a single pitch canker infection was found in Carmel-by-the-Sea, and in November 1993 a large number of infections were observed. Pitch canker has now become widespread on the Monterey Peninsula.

The second pitch canker-affected native stand of Monterey pine is at Año Nuevo State Reserve and the adjacent Coastways Ranch in San Mateo County. The only previous record of the pathogen from this area was from

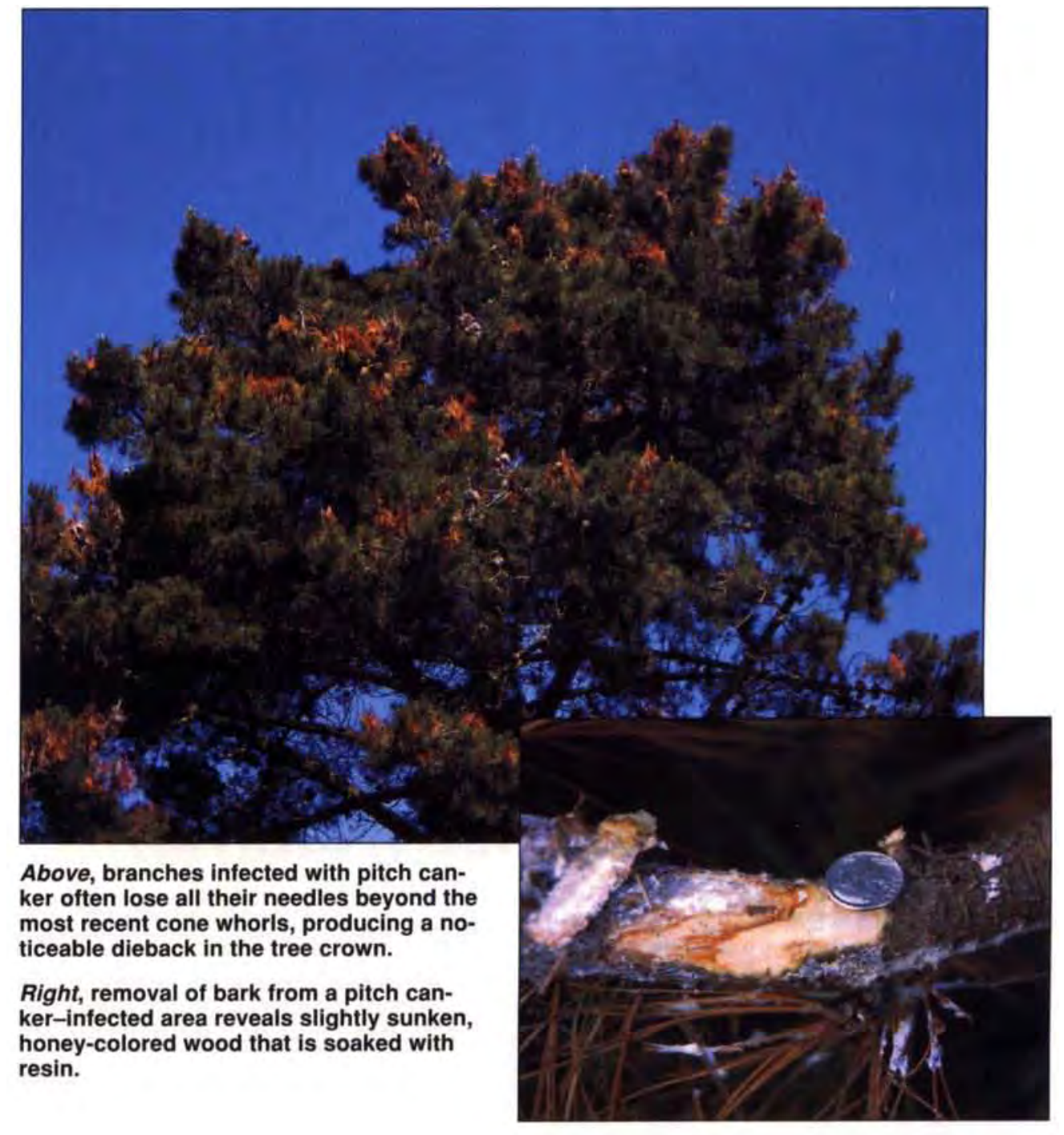

a young Monterey $\mathrm{x}$ knobcone pine hybrid. In December 1992 pitch canker was confirmed in Monterey pine Christmas trees at Coastways Ranch, and symptoms of the disease were observed on native trees, both at Coastways Ranch and at Año Nuevo State Reserve. Since that time the number of trees with symptoms of the disease has increased, and the disease has intensified on previously infected trees. Due to the inaccessibility locally of symptomatic tips, the disease on mature trees has not been confirmed by isolations. In November 1993 pitch canker was confirmed in native Monterey pines at Waddell Creek in Big Basin State Park, south of Año Nuevo Point.

The third native Monterey pine stand on the mainland, at Cambria, was not visited in 1992, and observations in 1993 and 1994 suggested that

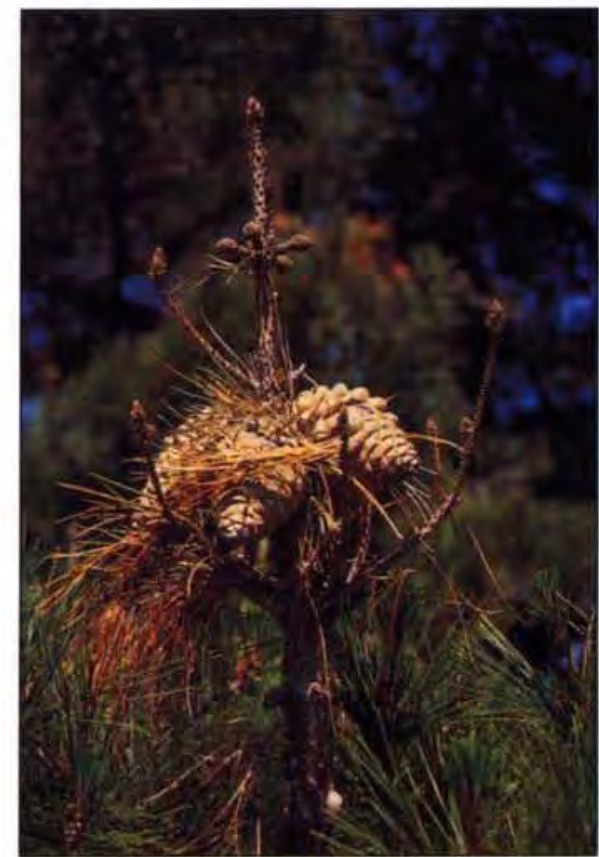

Female cones abort before or after reaching full size, and remain closed on infected whorls. 
trees in that area were free of the disease. The pitch canker pathogen has been isolated from many landscape planted Monterey pines in Morro Bay, San Luis Obispo County, which is less than 30 miles south of Cambria.

Pitch canker was found north of San Francisco for the first time in 1992. The disease was identified in a native Bishop pine stand near Highway 1 in Mendocino County in November. The pitch canker-affected trees were also suffering from dieback caused by western gall rust (Peridermium harknessii), and therefore branch tips exhibiting resinosis were selected for sampling. This record was reconfirmed in August 1993, when additional infected tree material was collected from the same area.

A Monterey pine was found infected with pitch canker at Ukiah, Mendocino County, at the junction of Talmage Road and U.S. Highway 101, in November of 1992. Isolations made in the field from this tree confirmed the presence of the pitch canker fungus. The pathogen was isolated in August 1993 from well-established infestations on Monterey pines in Santa Rosa, Sonoma County (reported to us by the California Department of Forestry and Fire Protection).

Infected Monterey pines have been found in several northern Alameda County locations including the Oakland and Berkeley hills, and in northern Monterey County. Intensification of the disease is occurring in these areas.

\section{Causes for concern}

Since early 1992 pitch canker has been found in four previously uninfected pine species, two of the three native mainland Monterey pine stands, a native Bishop pine stand, planted Monterey pine over 100 miles north of San Francisco, and urban plantings of Douglas fir. The continuing host and geographic range expansion of pitch canker is of great concern for a number of reasons.

Some of the infected tree species have very limited native distributions. Only one mainland native stand of Monterey pine remains uninfected, while the other two stands are now threatened by the presence of the dis-

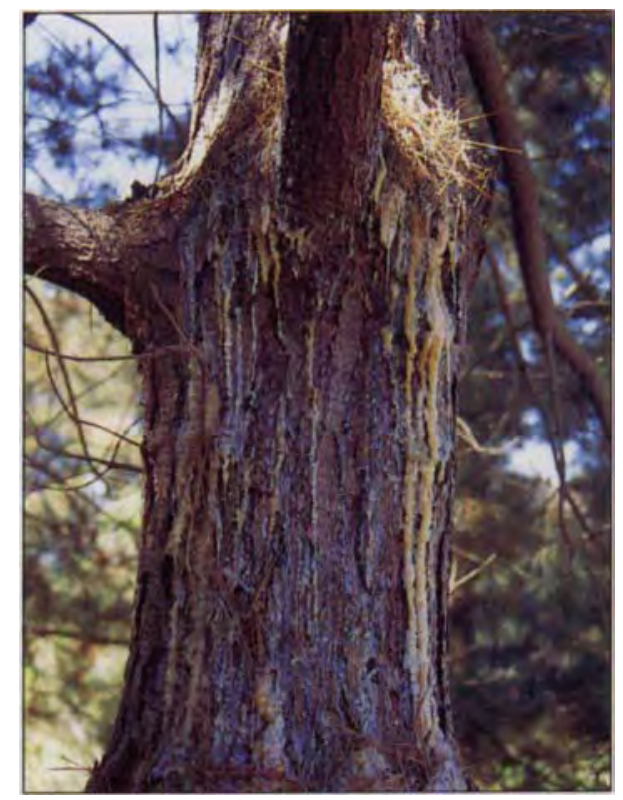

Cankers on the tree bole produce large amounts of resin that often coat the bark several feet below the infection site.

ease. Monterey pine is the most widely planted pine species in the world, and the presence of pitch canker in the native stands threatens a vital genetic resource. Similarly, Torrey pine has a very limited native distribution at Torrey Pine State Park, San Diego County, and has been shown to be susceptible in a landscape planting. The pitch canker pathogen affects Christmas trees at Escondido, San Diego County, which is less than 30 miles from Torrey Pine State Park. Native stands of Bishop pine are currently infected, and native shore pine stands to the north of San Francisco appear to be at risk. The potential is evident for the depletion of genetic diversity of certain pine species at their native sites.

The economic impact of pitch canker is increasing. The disease is causing considerable damage in Christmas tree plantations in Southern California, and we expect this to extend to other parts of the state in the future. One Christmas tree grower in Los Angeles County reported losing over 3,000 trees in 1992; losses increased in 1993. The disease is also known to occur in Christmas tree nurseries in Orange, San Diego and San Mateo Counties.

Commercially important timber species such as ponderosa and sugar pine may be at risk as pitch canker expands its range. Perhaps the most significant new record of pitch canker is from Douglas fir, a widespread tree species native to the western United States, which is of great economic importance. There are at least three possible avenues that the pathogen may take to the commercial timber stands in California. The disease may spread inland through isolated areas of planted Monterey pine and other suitable hosts as a corridor to the Sierra Nevada, or it may spread north or south to more complete host bridges through the Cascades or Southern Californian mountains. In Santa Cruz County, native stands of knobcone and ponderosa pines and Douglas fir are adjacent to some of the most heavily infected Monterey pine stands. The pathogen has been isolated from a single twig beetle that emerged from a cut branch of native ponderosa pine that was uninfested with insects when cut. Although as yet the pathogen has not been isolated from native ponderosa pine tissue, this record clearly represents an avenue by which the fungus may spread into native ponderosa pine stands.

Another economic impact of pitch canker results from the removal of ornamental plantings of Monterey pine. The cost may be considerable, especially where diseased trees are in close proximity to buildings and roadways. Costs associated with tree removal will increase as the disease intensifies and spreads into new areas.

\section{Should pines be planted?}

Monterey pines are at serious risk of infection by the pitch canker fungus. It is therefore not recommended that landscape plantings of Monterey pine be initiated in California at the present time. Work is underway to investigate the possibility of producing genetically resistant varieties of Monterey pine; if successful, it may be possible to resume ornamental plantings in the future. Pitch canker has resulted in significant mortality in Monterey pine Christmas tree plantations. Methods of reducing losses in this nursery environment are being investigated.

Destruction of cut and fallen branches and trees reduces the availability of breeding material for beetles 
that may transmit the fungus. Cut branches, prunings and fallen trees and branches should be chipped, debarked or burned to kill beetles breeding under the bark. Tools should be sterilized with Lysol before and after coming into contact with infected material. When pitch canker is manifested only as fading or killed tips, these may be removed by pruning. Cuts must be made well below the visibly affected part of the branch, which should be treated as described above. If the number of infected tips is very low and the affected tree is relatively isolated from other infected trees, pruning to remove all infections may slow the development of the disease. However, recent infections may not yet be symptomatic, so additional pruning may be required several weeks or months later.

No fungicidal or insecticidal treatments are effective in controlling pitch canker. The movement of infected tree tissue should be limited as much as possible. Fresh slash and recently cut logs or windthrown trees are known to act as reservoirs for the pathogen and the insects associated with it. Movement of infected material, including firewood, into areas free of the pathogen greatly increases the chance of introducing it into those areas.

The planting of other pine tree species should be undertaken with caution. Most species of pine, both native and exotic, that are commonly planted in urban landscapes are known to be susceptible. Many of the insect species that are associated with the pitch canker fungus in Monterey pine feed on, and may cause infections in, other pine species. For this reason it is recommended that no pines be planted in close proximity to Torrey Pine State Park, San Diego County. This will reduce the chance of pitch canker fungus becoming established in the very limited native stands of this species.

A.J. Storer is Postdoctoral Researcher, T.R. Gordon is Professor of Plant Pathology, P.L. Dallara is graduate student and D.L. Wood is Professor of Entomology, Division of Entomology, Plant and Soil Microbiology, UC Berkeley. Funding for this work was provided by the California Department of Forestry and Fire Protection.

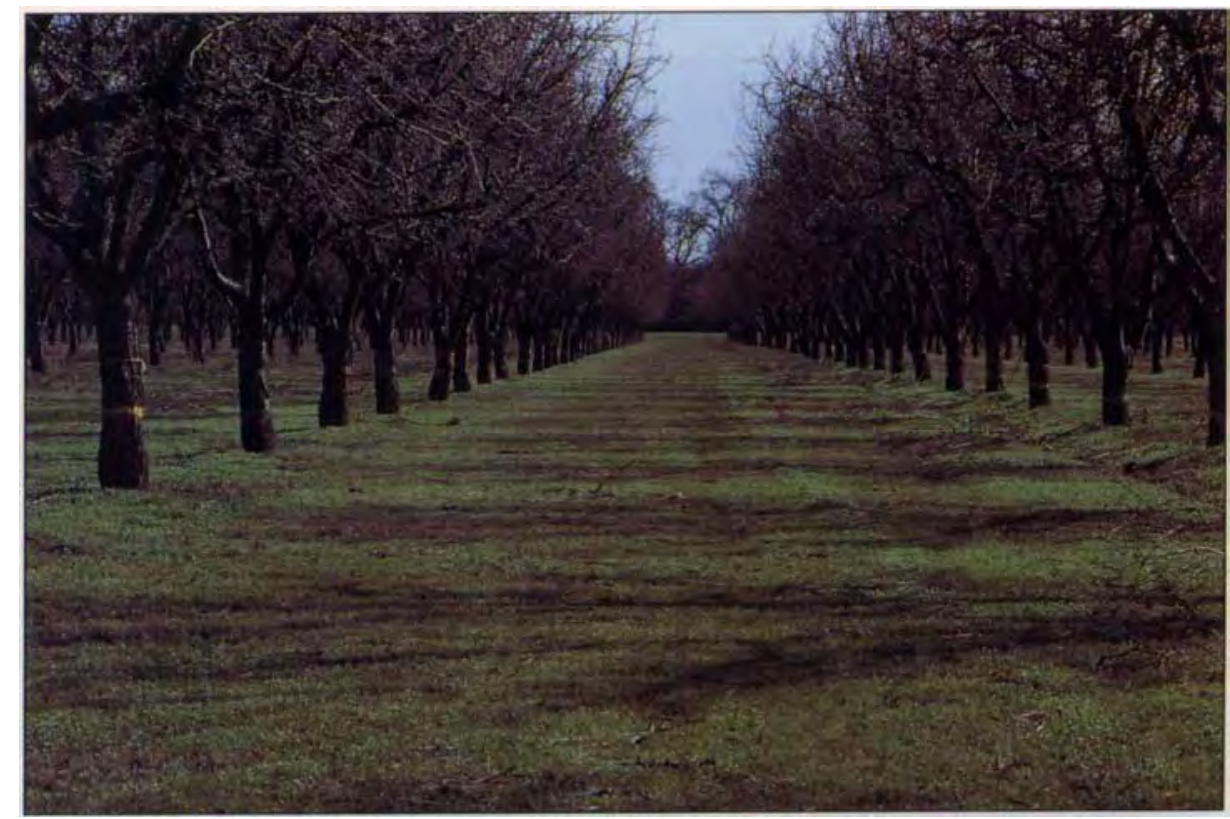

Alternate-year pruning may be more suitable for prune orchards with widely spaced trees like this, than vigorous orchards planted to higher tree densities.

\title{
Alternate-year pruning may provide temporary savings
}

\author{
Stephen M. Southwick \ James T. Yeager \ Maxwell Norton \\ Joseph Osgood \ Craig Weakley
}

Effects of alternate-year pruning over four seasons on fruit production, quality and net revenues per tree compare favorably to those for traditional annual pruning methods. Alternate-year pruning may be feasible for growers interested in reducing pruning costs in a particular season. However, the cost to prune trees in the alternate year significantly affects revenues per tree.

Pruning is done to develop tree structure, improve light penetration, remove dead and decayed wood and regulate cropping. The most critical benefit of mature tree pruning is crop regulation. Regular pruning is believed to improve fruit size and soluble solids while lowering fruitdrying ratios. Therefore, in most cases the economic benefits of pruning outweigh those of not pruning.
As farming costs continue to rise faster than revenues, growers are searching for ways to reduce expenses. For California prune growers, pruning is a significant production expense, often exceeding $\$ 125$ per acre, and is usually targeted when growers need to reduce farming costs. To cut current season production costs, it might be possible to prune in alternate years.

The actual effects of alternate-year pruning on fruit size, drying ratios, yield or other aspects of fruit quality have not been previously demonstrated. Alternate-year pruning poses some potential problems. In the nonpruned year, trees could produce more fruit of small size. Low soluble solid content and high fruit-drying ratios are associated with smaller fruit. Furthermore, large crops lead to tree limb breakage and tree top potassium deficiencies. These concerns are especially important following light 